\title{
Cow-to-cow variation in fibroblast response to a toll-like receptor 2/6 agonist and its relation to mastitis caused by intramammary challenge with Staphylococcus aureus
}

\author{
A. L. Benjamin, B. B. Green, L. R. Hayden, J. W. Barlow, and D. E. Kerr ${ }^{1}$ \\ Department of Animal Science, College of Agriculture \& Life Sciences, University of Vermont, Burlington 05405
}

\begin{abstract}
Staphylococcus aureus is a common cause of chronic mammary gland infections in dairy cattle. However, the inflammatory response and duration of infection following pathogen exposure is variable between individual animals. To investigate interanimal differences in immune response, dermal fibroblast cultures were established from skin biopsies collected from 50 early lactation Holstein cows. The fibroblasts ability to produce IL- 8 in response to a 24 -h treatment with a synthetic toll-like receptor $2 / 6$ agonist (Pam2CSK4) was used to assign a response phenotype to the animals. Five high-responding and 5 low-responding animals were then selected for an intramammary challenge with $S$. aureus to evaluate differences in the inflammatory response, chronicity of infection, and development of antibodies to the pathogen. All animals exhibited clinical symptoms of mastitis at $24 \mathrm{~h}$ postchallenge. Animals previously classified as high responders experienced a greater inflammatory response characterized by elevated levels of milk somatic cell count, IL-8, and BSA following the challenge compared with low responders. In addition, antibodies toward the challenge strain of $S$. aureus reached higher levels in whey from the challenged gland of high responders compared with low responders. Despite the antibody response, all 5 high responders were chronically infected for the 6 -wk duration of the study, whereas 2 of the low responders cleared the infection, although 1 of these did become reinfected. The observed differences between animals classified as low and high responders based on their fibroblast responsiveness suggests that this cell type can be used to further examine the causes of interanimal variation in response to mammary infection.
\end{abstract}

Key words: experimental mastitis, Pam2CSK4, interanimal variation, dairy cow

Received November 5, 2014.

Accepted December 1, 2014.

${ }^{1}$ Corresponding author: David.Kerr@uvm.edu

\section{INTRODUCTION}

Bovine mastitis can be caused by a variety of pathogens, resulting in variable degrees of inflammation of the infected mammary gland and subsequent decreases in milk production and quality (Ballou, 2012). Infections caused by Staphylococcus aureus typically result in a relatively mild inflammatory response with a sustained elevation in SCC; however, some animals will experience a more severe response, leading to collateral damage of the host (Atalla et al., 2009). These infections can develop into chronic, subclinical cases, in which infected animals maintain a reservoir of $S$. aureus on a farm (Bannerman et al., 2008; Schukken et al., 2011). Rates of mastitis due to $S$. aureus have decreased since the implementation of the 10-point plan from the National Mastitis Council (NMC, 2011), which recommends teat dipping and dry cow therapy as ways to minimize the spread of contagious pathogens. However, S. aureus is still present on most commercial herds, with incident rates ranging from 0.1 to $10 \%$ (Olde Riekerink et al., 2008; Barlow et al., 2013; Hertl et al., 2014). Treatment of long-term infections with antibiotics commonly yields an unsatisfactory cure rate (Sol et al., 2000; Barkema et al., 2006), and these animals are typically removed from the herd to limit spread of the pathogen.

Pathogens entering the mammary gland are recognized by toll-like receptors (TLR), which are found on multiple cell types within the gland and play a pivotal role in the innate immune response. These membranebound receptors are highly specific and identify conserved motifs known as pathogen-associated-molecularpatterns from various pathogens, including bacteria, fungi, and viruses (Takeuchi and Akira, 2010). For instance, LPS, a component of the Escherichia coli outer membrane, activates TLR4 (Park et al., 2009), and lipoproteins from the $S$. aureus cell wall activate TLR2 (Zähringer et al., 2008). Toll-like receptor signaling pathways lead to the activation of the transcription factor nuclear factor-kappa B (NF- $\kappa \mathbf{B})$, which regulates expression of various proinflammatory genes (Kawai and Akira, 2007). Increased expression of chemokines, 
such as IL-8, following NF- $\mathrm{BB}$ activation promotes recruitment of neutrophils to the site of infection. Neutrophils can account for up to $90 \%$ of the increased cell population within the infected gland and are the main cause of the rise in SCC following infection (Sordillo and Streicher, 2002).

Pathogen-specific differences in infection outcomes following experimentally induced mastitis and the resulting inflammatory responses have been observed (Bannerman, 2009). However, even in well-controlled situations considerable variation in response exists between individual animals. At the farm level, animals in similar physiological states under common environmental conditions also exhibit variable susceptibility to development of clinical mastitis. Various cell models have been used to investigate potential sources for these interanimal differences, including neutrophils (Sohn et al., 2007; Revelo and Waldron, 2012), monocyte-derived macrophages (Taraktsoglou et al., 2011), and mammary epithelial cells (Lahouassa et al., 2007; Brand et al., 2011). As model cells, neutrophils and macrophages are difficult to cryopreserve for future studies and can become activated during isolation and culturing processes, potentially adding to experimental variation. Mammary epithelial cells show a robust response to immunostimulants such as LPS, and these cells can successfully be cryopreserved (Wellnitz and Kerr, 2004; Pareek et al., 2005). However, although these cells can easily be isolated from tissue collected at euthanasia, procedures to isolate sufficient mammary tissue from live animals are relatively invasive and may compromise the ability of the gland to return to full production. We have previously examined the autologous dermal fibroblast as a model cell to predict an animal's responsiveness to experimental E. coli mastitis (Kandasamy et al., 2011). The fibroblast is easily obtainable and, following isolation, the cells can be cultured quickly and cryopreserved. Cultured fibroblasts also demonstrate a robust response following stimulation with various TLR agonists (Kandasamy and Kerr, 2012), suggesting that it may be a useful cell type to explore the underlying causes for interanimal variation in response to mastitis. In the current study we extend these findings to include experimentally induced $S$. aureus mastitis.

\section{MATERIALS AND METHODS}

\section{Animal and Experimental Procedures}

The University of Vermont's Institutional Animal Care and Use Committee approved all animal procedures before commencement of the study. Dermal fibroblast cultures were established from skin samples collected from 50 lactating Holstein cows housed at a collaborating dairy farm. Animals were randomly enrolled in the study, and at the time of biopsy were in early to mid lactation $(117 \pm 30$ DIM $)$. The average lactation number of the 50 enrolled cows was $2.8( \pm 0.9)$.

Skin samples were collected as described previously (Kandasamy et al., 2011) with slight modifications. Briefly, a $6-\mathrm{cm}^{2}$ skin sample was taken from the shoulder area following standard surgical preparation of the site and transported back to the laboratory on ice in Dulbecco's PBS (DPBS; Hyclone Laboratories, Logan, UT) supplemented with a $1 \times$ antibiotic cocktail $(100$ $\mathrm{U} / \mathrm{mL}$ of penicillin, $100 \mu \mathrm{g} / \mathrm{mL}$ of streptomycin, and $0.25 \mu \mathrm{g} / \mathrm{mL}$ of amphotericin B; Hyclone Laboratories). After removing subcutaneous fat and connective tissue, a $3-\mathrm{cm}^{2}$ piece of skin was minced into smaller pieces with opposing scalpel blades and subsequently washed 4 times with fresh DPBS. After washing, 10 $\mathrm{mL}$ of $0.5 \%$ collagenase type I enzyme (Life Technologies, Grand Island, NY) diluted in Dulbecco's modified Eagle medium (DMEM; Hyclone) containing $1 \times$ antibiotic cocktail was added to the minced skin pieces and incubated at $37^{\circ} \mathrm{C}$ for $6 \mathrm{~h}$ with orbital shaking. The collagenase-digested tissue was then filtered through a $70-\mu \mathrm{m}$ nylon mesh filter (Fisher Scientific, Pittsburgh, $\mathrm{PA}$ ), and the filtrate was centrifuged at $1,100 \times g$ for 5 min at $20^{\circ} \mathrm{C}$. The cell pellet was reconstituted with DMEM containing 10\% fetal bovine serum (FBS; Hyclone Laboratories), $1 \times$ insulin-transferrin-selenium (Mediatech Inc., Herndon, VA), and $1 \times$ antibiotic cocktail and cultured in a $25-\mathrm{cm}^{2}$ flask (Corning Inc., Corning, NY) in a humidified $37^{\circ} \mathrm{C}$ incubator with $5 \%$ $\mathrm{CO}_{2}$ until $70 \%$ confluency was reached. Cells were then detached with $0.25 \%$ trypsin (MP Biomedical, Santa Ana, CA) and seeded in a $75-\mathrm{cm}^{2}$ flask (Corning Inc.) with DMEM supplemented with 5\% FBS, $1 \times$ insulintransferrin-selenium, and $1 \times$ antibiotic cocktail. After approximately $4 \mathrm{~d}$, cells were trypsinized and split into three $75-\mathrm{cm}^{2}$ flasks. Once cells reached confluency, they were lifted with trypsin and aliquots of the third passage were diluted in DMEM supplemented with $20 \%$ FBS and 10\% dimethyl sulfoxide (Sigma-Aldrich, St. Louis, MO) and cryopreserved in liquid nitrogen for future challenges.

\section{Dermal Fibroblast Challenges with IL-1 $\beta$, LPS, and Pam2CSK4}

Aliquots of cells were revived from cryopreservation in duplicate and cultured in a $75-\mathrm{cm}^{2}$ flask until confluent. Cells were lifted with trypsin and fourth-passage cells were seeded into a 6 -well plate (Corning Inc.) at $1 \times 10^{5}$ cells $/ \mathrm{mL}$ in a total volume of $2 \mathrm{~mL}$. Following a 24-h incubation, media was removed and replaced with $2 \mathrm{~mL}$ of fresh media (negative control), or media 
containing either $1 \mathrm{ng} / \mathrm{mL}$ of recombinant bovine IL-1 $\beta$ (AbD Serotec, Raleigh, NC), $100 \mathrm{ng} / \mathrm{mL}$ of ultra-pure LPS isolated from E. coli 0111:B4 (Sigma-Aldrich), or $200 \mathrm{ng} / \mathrm{mL}$ of a synthetic TLR2/6 agonist Pam2CSK4 (PAM2; Invivogen, San Diego, CA). After $24 \mathrm{~h}$ of exposure, media was collected from each well, spun at $10,000 \times g$ for $1 \mathrm{~min}$ to remove cell debris, and stored at $-20^{\circ} \mathrm{C}$ until future analysis.

\section{IL-8 and IL-6 ELISA}

The concentration of IL- 8 in conditioned media samples was quantified by a custom sandwich ELISA as previously described (Kandasamy et al., 2011). Mouse anti-bovine IL-8 (clone 170.13 from Samuel Maheswaren, University of Minnesota, St. Paul) and biotinylated goat anti-human IL-8 (R\&D Systems Inc., Minneapolis, MN) were used as capture and detection antibodies, respectively, and recombinant bovine IL-8 (Thermo Scientific, Rockford, IL) as the assay standard. The concentration of IL-6 in conditioned media was determined with a commercially available bovine IL-6 ELISA kit (Thermo Scientific). The capture and detection antibodies were plated at 1:100 and the streptavidin-horseradish peroxidase was plated at 1:400. Recombinant bovine IL-6 was used as the assay standard (Thermo Scientific).

\section{Preparation of S. aureus Inoculum}

A cryopreserved $S$. aureus specimen of multilocus sequence type 8 , originally isolated from milk of a cow with chronic subclinical mastitis (Barlow et al., 2013), was streaked on a trypticase soy agar plate with $5 \%$ sheep blood (Northeast Laboratory Services, Waterville, ME) and incubated at $37^{\circ} \mathrm{C}$ for $16 \mathrm{~h}$. One bacterial colony was then used to inoculate $3 \mathrm{~mL}$ of trypticase soy broth and incubated at $37^{\circ} \mathrm{C}$ with shaking for $6 \mathrm{~h}$. Afterward, $1 \mathrm{~mL}$ of the inoculated broth was placed in $99 \mathrm{~mL}$ of trypticase soy broth and incubated for $16 \mathrm{~h}$ at $37^{\circ} \mathrm{C}$ with shaking. This stock culture was stored for $24 \mathrm{~h}$ at $4^{\circ} \mathrm{C}$ while the bacterial concentration $(\mathrm{cfu} / \mathrm{mL})$ was determined by serial dilution and plate counting.

\section{Intramammary Challenge}

Ten of the 50 skin-biopsied animals were selected for an intramammary challenge based on the production of IL-8 protein by their dermal fibroblasts in response to stimulation with PAM2. Five of the animals were designated as low responders (LR), as their fibroblast production of IL- 8 ranked in the lowest $20 \%$ of the 50 animal fibroblast pool, and 5 animals were designated as high responders (HR), as their fibroblast produc- tion of IL-8 ranked in the highest $20 \%$. The animals averaged $235( \pm 30)$ DIM and were transported to the University of Vermont 1 wk before the challenge. Four LR and $4 \mathrm{HR}$ animals were confirmed pregnant at the time of challenge (122 $\pm 34 \mathrm{~d}$ pregnant), and controlled internal drug releasers (a progesterone insert, EaziBreed CIDR, Pfizer, New York, NY) were placed in the 2 nonpregnant animals to control hormonal fluctuations. Throughout the trial, animals were milked with individual milking units that were sanitized before each milking. Quarter milk samples collected before experimental infection were negative for mastitis pathogens and composite milk SCC were below 200,000 cells/mL. On the day of the challenge, teat ends were disinfected with $70 \%$ ethanol and $5 \mathrm{~mL}$ of the prepared bacterial suspension diluted in endotoxin-free, isotonic sterile saline was infused with the aid of a teat cannula into the right hind quarter of each animal. Plating of the bacterial infusion solution, followed by colony counting, indicated each animal received $200 \mathrm{cfu}$ in total in the right hind quarter. Milk samples were collected from the infected and control quarters just before infusion and at various times for 6 wh postinfusion (PI). Bacteria counts in milk from individual challenged and control quarters were determined by plating $100 \mu \mathrm{L}$ of neat or diluted milk samples, incubating at $37^{\circ} \mathrm{C}$ for 24 $\mathrm{h}$, and counting bacterial colonies. Milk SCC was determined with a portable cell counter (DCC, DeLaval, Tumba, Sweden). Rectal temperatures of each animal were monitored for $4 \mathrm{~d}$ PI.

\section{Whey Preparation}

Milk samples from the infected and control quarters were centrifuged at $16,000 \times g$ for $30 \mathrm{~min}$ at $4^{\circ} \mathrm{C}$. The fat layer was discarded and the milk was centrifuged a second time at $16,000 \times g$ for $30 \mathrm{~min}$ at $4^{\circ} \mathrm{C}$. The clear supernatant was collected and stored at $-20^{\circ} \mathrm{C}$ for future analysis. Levels of IL-8 protein in whey were determined by ELISA as described previously, and concentrations of BSA in whey were determined using commercial ELISA reagents (Bethyl Laboratories, Montgomery, TX) according to manufacturer directions.

\section{Humoral Response Following S. aureus Challenge}

Total anti-S. aureus IgG antibody levels in plasma and whey were determined by ELISA as described by Leitner et al. (2000) with some modifications. A stock of the $S$. aureus challenge strain was prepared as described previously for the intramammary challenge, however, the $100 \mathrm{~mL}$ of 16 -h growth was subjected to heat-killing at $70^{\circ} \mathrm{C}$ for $45 \mathrm{~min}$ with shaking every $10 \mathrm{~min}$. Aliquots of this stock were stored at $-20^{\circ} \mathrm{C}$ for subsequent as- 
says. Wells of a 96-well ELISA plate were coated with either $100 \mu \mathrm{L}$ of $1 \times 10^{7}$ heat-killed bacteria diluted in $0.05 M$ bicarbonate buffer or $100 \mu \mathrm{L}$ of $0.05 M$ bicarbonate buffer (a blank well) and incubated at $4^{\circ} \mathrm{C}$ overnight. Plates were washed 3 times with DPBS-0.05\% Tween-20 (DPBS-T; Fisher Bioreagents, Fair Lawn, NJ), then $100 \mu \mathrm{L}$ of a $2 \%$ nonfat milk (Lab Scientific, Highlands, NJ) solution diluted in DPBS was added to each well and incubated for $1 \mathrm{~h}$ at room temperature. Following plate washing, $100 \mu \mathrm{L}$ of plasma or whey samples diluted 1:800 or 1:10, respectively, in DPBS-T were plated and incubated at room temperature for $1 \mathrm{~h}$. Plates were washed again and $100 \mu \mathrm{L}$ of a $0.025-\mu \mathrm{g} / \mathrm{mL}$ solution of a biotinylated polyclonal goat anti-cow $\operatorname{IgG}$ (Fisher Scientific), or $100 \mu \mathrm{L}$ of a $0.2-\mu \mathrm{g} / \mathrm{mL}$ solution of a biotinylated polyclonal sheep anti-bovine $\operatorname{IgG}_{1}$ or $\mathrm{IgG}_{2}$ (Thermo Scientific) diluted in DPBS-T was plated and incubated at room temperature for $1 \mathrm{~h}$. Lastly, after washing, tetramethylbenzidine substrate (Thermo Scientific) was added to each well and the reaction was stopped with $1 \mathrm{M} \mathrm{H}_{2} \mathrm{SO}_{4}$ after approximately $2 \mathrm{~min}$. The absorbance at $450 \mathrm{~nm}$ was determined using a 4-parameter analysis with optical density correction for blank wells (Synergy-HT, Bio-Tek).

\section{Fibroblast Gene Expression in Response to Pam2CSK4}

Gene expression analysis was performed on fibroblast cultures from the animals that were selected for intramammary challenge. Fibroblasts from the 10 challenged animals $(\mathrm{n}=5 \mathrm{LR}, \mathrm{n}=5 \mathrm{HR})$ were revived from cryopreservation, and cultured in a $75-\mathrm{cm}^{2}$ flask. Once confluent, cells were lifted with $0.25 \%$ trypsin, counted, and seeded into 6 -well plates at a concentration of $1 \times$ $10^{5}$ cells $/ \mathrm{mL}$. Following a 24 -h incubation, fibroblasts were exposed to $200 \mathrm{ng} / \mathrm{mL}$ of PAM2 and RNA was collected at 3 time points: h 0 (control conditions) and $\mathrm{h} 2$ and 8 postchallenge using the RNeasy Mini Kit (Qiagen, Valencia, CA) according to manufacturer directions. Following extraction, RNA concentrations were assessed using the Qubit 2.0 Fluorometer (Life Technologies). First-strand cDNA synthesis was completed using the Improm II Reverse Transcriptase Kit (Promega, Madison, WI). Expression levels of selected immune genes were determined by quantitative realtime PCR (qRT-PCR) with a 7500 Fastrun Machine (Applied Biosystems, Carlsbad, CA) using Fermentas Maxima SYBR Green/Fluorescein qPCR Mastermix (Thermo Scientific). Messenger RNA expression for target genes was normalized against $\beta$-actin, an endogenous control gene. Fold differences in target gene expression are presented as the difference between HR and LR cultures at the indicated hour post-PAM2. Sequences for the constructed oligonucleotide primers are presented in Table 1.

\section{Statistical Analysis}

Correlations between IL-8 and IL-6 responses from dermal fibroblasts following $24 \mathrm{~h}$ of exposure to IL$1 \beta$, LPS, and PAM2 were calculated by linear regression using the statistical software package Prism 6.0 (GraphPad Software Inc., La Jolla, CA). Differences between production of IL- 6 and IL- 8 from paired fibroblast biopsies were determined by paired $t$-test in Prism 6.0. Milk SCC and colony-forming unit counts were $\log _{10}$ transformed before analysis. Effects of phenotype (LR or HR) on levels of milk IL-8, BSA, SCC, bacteria counts, right hind quarter milk production, and plasma and whey levels of total $\operatorname{IgG}$ as well as $\operatorname{IgG}_{1}$ and $\operatorname{IgG}_{2}$ were analyzed with a linear mixed model assuming a first-order auto-regressive covariance structure, with time postinfusion as the repeated measure. Analyses were performed with the MIXED procedure in SAS version 9.4 (SAS Institute Inc., Cary, NC). Changes in

Table 1. Oligonucleotide primers used for real-time PCR quantification (top and bottom sequences are the forward and reverse, respectively)

\begin{tabular}{|c|c|c|}
\hline Gene name & Sequence $\left(5^{\prime}\right.$ to $\left.3^{\prime}\right)$ & Reference \\
\hline Toll-like receptor 2 & $\begin{array}{l}\text { GGTTTTAAGGCAGAATCGTTTG } \\
\text { AAGGCACTGGGTTAAACTGTGT }\end{array}$ & Akira et al. (2001) \\
\hline Toll-like receptor 6 & $\begin{array}{l}\text { CCTTGTTTTTCACCCAAATAGC } \\
\text { TAAGGTTGGTCCTCCAGTGAGT }\end{array}$ & Akira et al. (2001) \\
\hline$I L-8$ & $\begin{array}{l}\text { GCTGGCTGTTGCTCTCTTG } \\
\text { AGGTGTGGAATGTGTTTTTATGC }\end{array}$ & Pareek et al. (2005) \\
\hline Chemokine (C-C motif) ligand 20 & $\begin{array}{l}\text { TTCGACTGCTGTCTCCGATA } \\
\text { GCACAACTTGTTTCACCCACT }\end{array}$ & Gilbert et al. (2013) \\
\hline$I L-6$ & $\begin{array}{l}\text { TGAGGGAAATCAGGAAAATGT } \\
\text { CAGTGTTTGTGGCTGGAGTG }\end{array}$ & Pareek et al. (2005) \\
\hline Tumor necrosis factor- $\alpha$ & $\begin{array}{l}\text { TCTTCTCAAGCCTCAAGTAA } \\
\text { CCATGAGGGCATTGGCATAC }\end{array}$ & Bougarn et al. (2011) \\
\hline$\beta$-actin & $\begin{array}{l}\text { GCAAATGCTTCTAGGCGGACT } \\
\text { CAATCTCATCTCGTTTTCTGCG }\end{array}$ & Pareek et al. (2005) \\
\hline
\end{tabular}


expression of selected immune genes between LR and HR animals were analyzed using a one-tailed $t$-test. Differences with a $P<0.05$ were considered significant.

\section{RESULTS}

\section{Stimulation of Dermal Fibroblasts}

Isolated fibroblasts from all 50 cows were revived from cryopreservation, cultured, and subsequently challenged for $24 \mathrm{~h}$ with PAM2. The concentrations of secreted IL-8 in media following duplicate challenges are presented in Figure 1A. There was a wide range of responsiveness to PAM2, with the mean IL- 8 of the highest $10 \%$ of animals being more than 8 -fold greater $(P<0.05)$ than the mean of the lowest $10 \%$ of animals $(1243 \pm 119$ vs. $142 \pm 11 \mathrm{pg} / \mathrm{mL}$, respectively). The detection limit of the assay was approximately $130 \mathrm{pg} /$ $\mathrm{mL}$.

The relationships between IL- 8 production by the 50 fibroblast cultures following challenges with LPS and IL-1 $\beta$ were also investigated and compared with the response to PAM2 (data not shown). The levels of secreted IL-8 were correlated between the IL-1 $\beta$ and LPS responses $\left(P<0.01, \mathrm{R}^{2}=0.63\right)$, the LPS and PAM2 responses $\left(P<0.05, \mathrm{R}^{2}=0.46\right)$, and the IL-1 $\beta$ and PAM2 responses $\left(P<0.01, \mathrm{R}^{2}=0.80\right)$. To investigate the within-animal stability of the fibroblast response, a second skin biopsy was collected from the 10 animals that had been selected for the in vivo $S$. aureus challenge. This second biopsy was obtained at slaughter on d 40 postchallenge, which was approximately 5 mo after the initial biopsy. Unfortunately, 1 of the second HR biopsies did not yield a viable culture due to microbial contamination and was discarded. Fourth passage cultures from the first and second biopsy were revived simultaneously from cryopreservation and challenged in parallel wells with PAM2 for $24 \mathrm{~h}$. The resulting media concentrations of IL- 8 and IL-6 are presented in Figure $1 \mathrm{~B}$ and $\mathrm{C}$, respectively. Responses between replicate biopsies from the same animal were nearly identical for IL-8 with the difference in response magnitude between the LR and HR animals being approximately 4 -fold. Responses for IL-6 were also quite similar between the 2 biopsies. The production of IL- 8 and IL- 6 following PAM2 treatment was highly correlated between replicate biopsies $\left(P<0.01, \mathrm{R}^{2}=0.95\right.$ and $P<0.01, \mathrm{R}^{2}=$ 0.75 , for IL-8 and IL-6, respectively).

\section{Rectal Temperature, and Milk Yield, SCC, and Bacterial Counts Following Intramammary Infusion of S. aureus}

Each of the 10 selected animals received a single intramammary infusion of the challenge strain of $S$. au- reus and by $24 \mathrm{~h}$ PI, all animals had evidence of mammary swelling and clots in the milk from the challenged quarter. Rectal temperatures in all animals showed a moderate increase that peaked at approximately 30 $\mathrm{h}$ PI, with no difference between LR and HR groups (Figure 2).

Milk yield from the right hind quarter (RHQ) is shown in Figure 3A, and although the HR animals produced less milk from the challenged quarter throughout most of the study, this difference was not significant. However, a reduction in quarter milk yield was observed in both groups following the infusion, which reached its lowest value between 48 to $60 \mathrm{~h}$ PI.

Immediately before the infusion, milk SCC of each challenged quarter was below 200,000 cells/mL; however, in response to the pathogen, it peaked at approximately $15 \times 10^{6}$ cells $/ \mathrm{mL}$ (Figure $3 \mathrm{~B}$ ). At $24 \mathrm{~h} \mathrm{PI}$, the HR SCC $\left(5.2 \times 10^{6}\right.$ cells $\left./ \mathrm{mL}\right)$ was approximately 10 -fold greater than the LR SCC $\left(3.1 \times 10^{5}\right.$ cells $\left./ \mathrm{mL}\right)$, demonstrating a delayed influx of immune cells into the infected gland of the LR animals. Although milk SCC of both groups was elevated above preinfection levels throughout the study, HR animals had higher $(P<$ 0.05) SCC in the RHQ milk when compared with LR animals.

Bacterial load was monitored for 6 wk following the intramammary challenge. The challenge strain was recovered from milk samples collected from the RHQ of all animals $24 \mathrm{~h}$ after infusion (Figure 3C). One LR animal was culture negative at $84 \mathrm{~h}$ PI and maintained culture negative status for the reminder of the study. A second LR animal was culture negative at $108 \mathrm{~h} \mathrm{PI}$, but at $336 \mathrm{~h}$ PI (d 14) the challenge strain was reisolated from the RHQ and this animal remained infected until the end of the study. Whereas bacterial counts were not significantly different between the 2 groups, none of the HR animals were culture negative during the trial.

\section{Inflammatory Markers Present in Challenged Quarter Whey}

The concentration of IL-8 in whey from the RHQ was undetectable until $24 \mathrm{~h}$ PI in both LR and HR groups (Figure 4A). Levels of IL-8 rose quickly after $24 \mathrm{~h}$, however, and HR animals produced a greater $(P<0.05)$ amount of IL-8 following challenge when compared with LR animals. Concentrations of BSA in whey began to increase by $24 \mathrm{~h}$ PI and reached a maximum value of almost $3 \mathrm{mg} / \mathrm{mL}$ at $72 \mathrm{~h}$ PI in the HR animals (Figure 4B). A similar profile was observed in the LR animals, although the rise in BSA was somewhat delayed and the overall magnitude of the response was lower $(P<$ 0.05) than in the HR animals. 
A

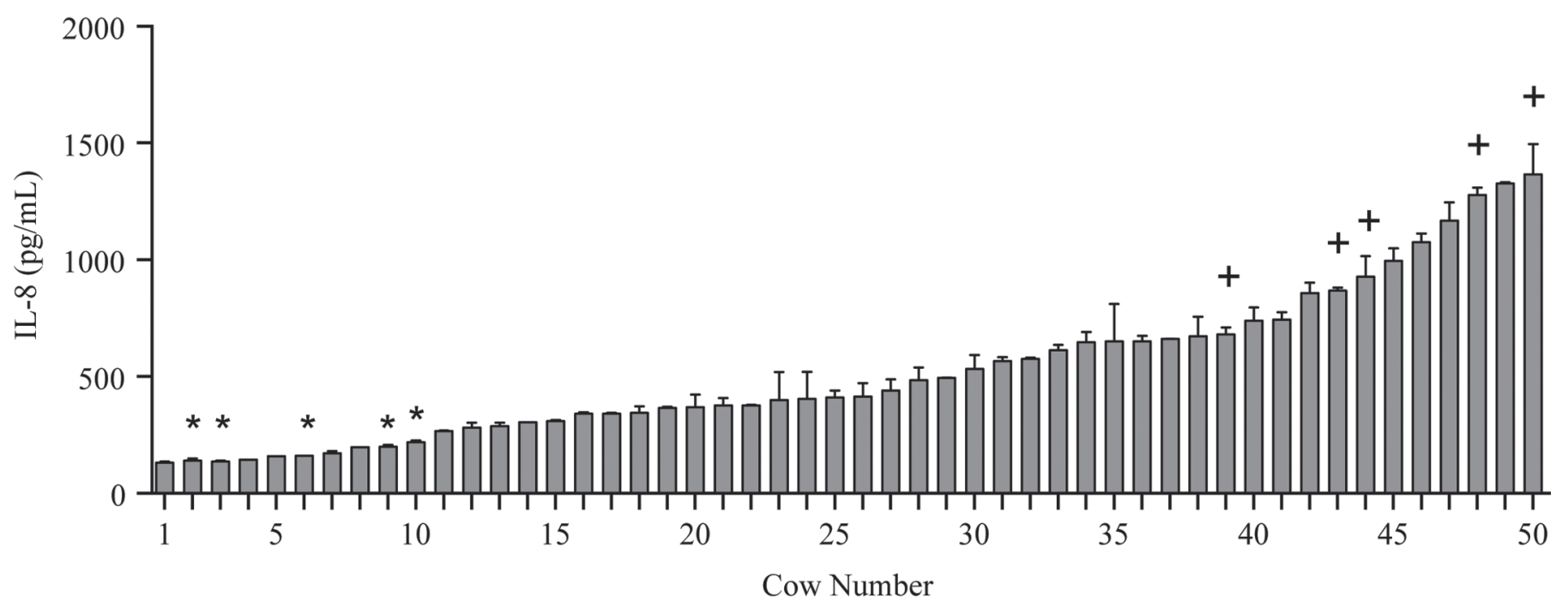

B

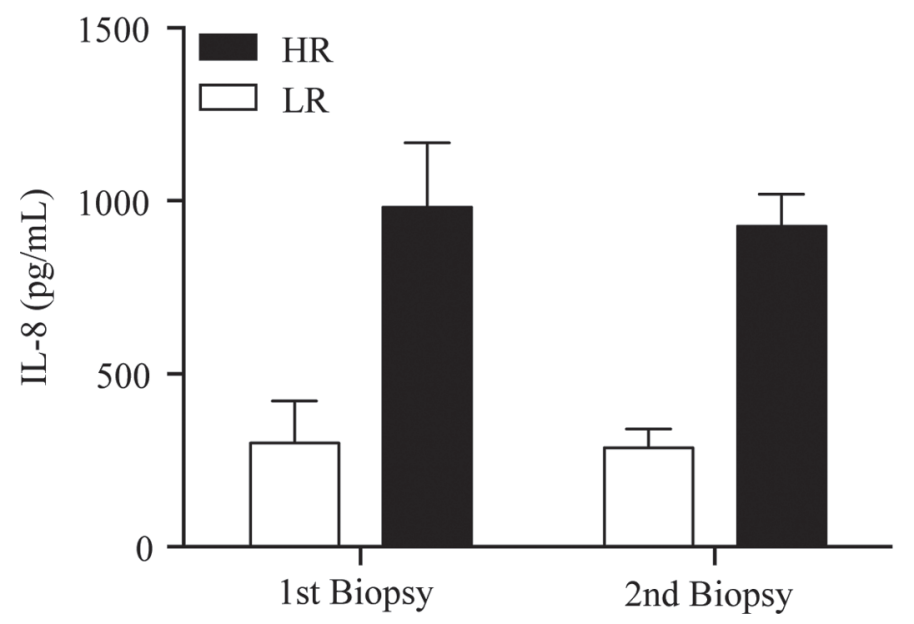

$\mathrm{C}$

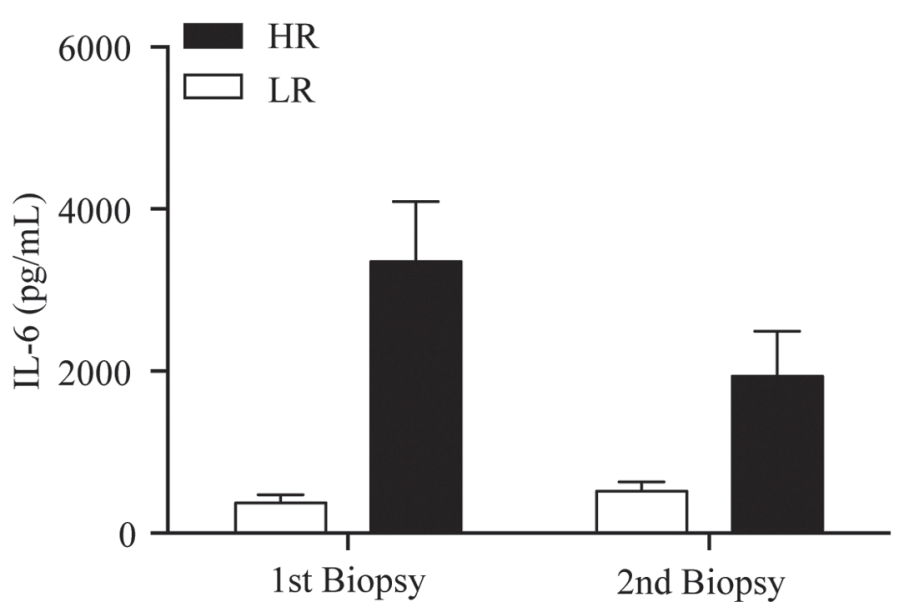

Figure 1. (A) Concentrations of IL-8 in fibroblast culture media following a $24 \mathrm{~h}$ challenge with $200 \mathrm{ng} / \mathrm{mL}$ of a synthetic toll-like receptor $2 / 6$ agonist (PAM2). An asterisk $\left(^{*}\right)$ and a plus sign $(+)$ indicate the low-responding (LR) and high-responding (HR) animals, respectively, that were selected for an in vivo Staphylococcus aureus challenge. Cells cultured in media alone (negative control) produced no detectable IL-8. Values are mean \pm SEM of 2 replicates. (B) Interleukin-8 and (C) IL-6 protein concentrations in media following a 24-h challenge with PAM2 of fibroblasts isolated from the selected animals approximately 5 mo before and 6 wk after an experimental challenge with $S$. aureus. For the first biopsy $n=5 \mathrm{LR}$ and $\mathrm{n}=5 \mathrm{HR}$, for the second biopsy $\mathrm{n}=5 \mathrm{LR}$ and $\mathrm{n}=4 \mathrm{HR}$ ( 1 second HR biopsy did not yield a viable culture due to microbial contamination and was discarded). Concentrations of IL- 8 and IL-6 were similar between replicate biopsies from animals within the LR and HR groups $(P>0.05$; paired $t$-test). Media wells had no detectable IL-8 or IL-6.

\section{Plasma and Whey Antibodies to S. aureus}

Levels of anti-S. aureus total IgG in plasma and total $\mathrm{IgG}, \mathrm{IgG}_{1}$, and $\mathrm{IgG}_{2}$ in RHQ whey samples were measured by ELISA for $36 \mathrm{~d}$ after the challenge. On d 0, the levels of anti-S. aureus total IgG in whey and plasma were similar between LR and HR animals (Figure 5A and B). The antibody levels increased in the weeks following the challenge, primarily in the HR animals, such that overall levels of anti- $S$. aureus total IgG were higher $(P$ $<0.05)$ in the HR when compared with the LR animals (Figure 5A and B). Furthermore, this greater response in the HR animals was mirrored by greater increases $(P<$ $0.05)$ in whey levels of the $\mathrm{IgG}_{2}$ isotype of anti- $S$. aureus antibody as compared with LR animals, whereas $\operatorname{IgG}_{1}$ levels were similar between the groups. 


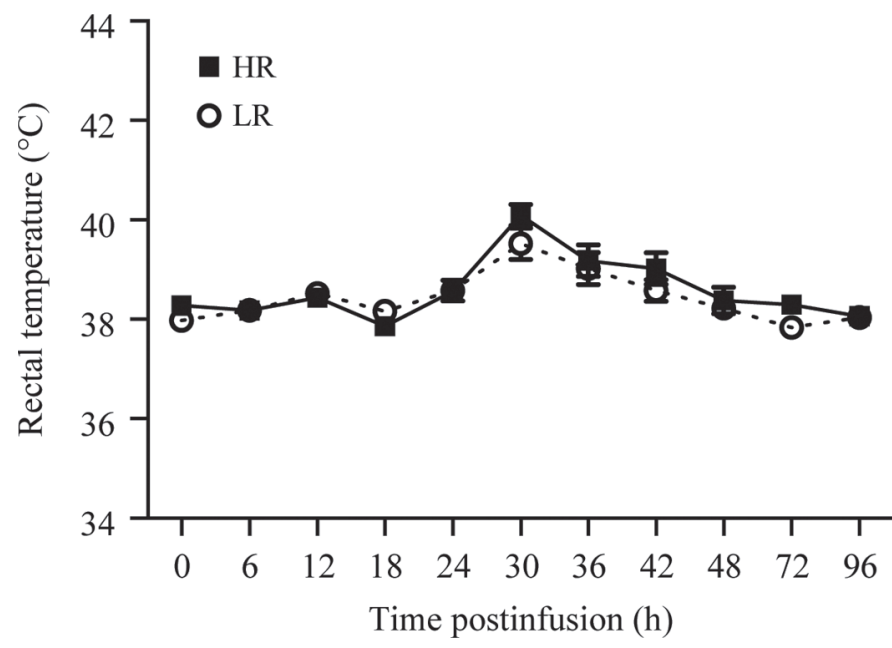

Figure 2. Rectal temperatures were monitored after a single intramammary infusion of Staphylococcus aureus in the right hind quarter of the 10 challenged animals. Values are expressed as mean \pm SEM There were no significant differences in rectal temperatures following the challenge between low-responder (LR) and high-responder (HR) animals.

\section{Fibroblast Gene Expression in Response to PAM2}

Aliquots of dermal fibroblasts from the 10 animals selected for intramammary challenge were revived from cryopreservation to investigate potential differences in expression of select immune genes in response to PAM2. Total RNA was extracted at h 0 (control conditions), 2 , and 8 posttreatment. One component of the PAM2 recognition pathway, TLR2, was induced $(P<0.05)$ by PAM2 stimulation, whereas the other component, TLR6, was not (Figure 6A and B, respectively). Genes associated with an inflammatory response, including $I L-8, C C L 20, I L-6$, and $T N F-\alpha$, were induced above control levels following PAM2 treatment $(P<0.05$; Figure $6 \mathrm{C}, \mathrm{D}, \mathrm{E}$, and $\mathrm{F}$, respectively). These 6 genes were generally expressed at a numerically higher level in the HR cultures than in the LR cultures. Significantly greater expression $(P<0.05)$ in the HR cultures was found for TLR2 and $I L-6$ at $8 \mathrm{~h}$, and for $I L-8$ at $0 \mathrm{~h}$ post-PAM2. Expression of $C C L 20(P=0.06)$ and TNF- $\alpha(P=0.11)$ at $2 \mathrm{~h}$ and TLR6 $(P=0.06)$ at $8 \mathrm{~h}$ post-PAM2 showed a trend toward higher levels in HR cultures compared with LR cultures.

\section{DISCUSSION}

In the current study, dermal fibroblasts isolated from adult dairy cattle were used as a cellular model to predict the magnitude of an animal's inflammatory response to an intramammary $S$. aureus challenge. The concept stems from the substantial variation that exists between cows and between cases within cows in the response to mammary gland infection. Differences in pathogen type and strain, differences in farm environment and resulting infection pressure, and differences in physiological state of the animal certainly contribute to variation in incidence and severity of mastitis (Burvenich et al., 2003; Wenz et al., 2006, 2010). However, considerable variation is also observed under controlled experimental challenges with either E. coli (Kornalijnslijper et al., 2004) or S. aureus (Schukken et al., 1999). In the study by Schukken et al. (1999), 135 lactating cows were challenged by intramammary infusion of $S$. aureus into all quarters. Infection status was then determined 2, 3, and $4 \mathrm{wk}$ PI. The range of resulting infection status included $20.7 \%$ of cows that did not establish infection in any of the quarters, $15.6 \%$ of cows with 1 quarter infected, $25.9 \%$ with 2 quarters infected, $17.8 \%$ with 3 quarters infected, and $20.0 \%$ with all quarters infected. Thus, it seems clear from their study that some cows are inherently more resistant to $S$. aureus mastitis than other cows. Our hypothesis was that range of endogenous innate responsiveness to mammary gland infection exists within the cow population and that the high-responsive phenotype is the one more prone to develop severe mastitis associated with greater tissue damage and compromised return to full production (Kandasamy et al., 2011). Our goal was to develop an ex vivo technique that could be of use in identifying genetic polymorphisms or epigenetic effects contributing to an animal's innate immune response phenotype, leading to more accurate breeding and selection strategies aimed at reducing mastitis severity. Thus, determination of an animal's innate response phenotype at a young age (Green et al., 2011) could be of use in selecting those calves that would be ideal candidates for milking herd replacements as opposed to being more appropriate for beef production. Current costs of raising herd replacements are estimated at greater than $\$ 1,500$, depending on farm-management practices (Heinrichs et al., 2013). Testing of existing animals at a young age would also incorporate the effects of epigenetic modification on gene expression that may have occurred from early life environmental conditions.

Use of primary fibroblasts as an ex vivo model system is well documented for other species (Rogers et al., 2007; Wang et al., 2011; Schramm et al., 2012), demonstrating the ability of these cells to produce inflammatory markers, such as IL-6 and IL-8, or exhibit altered gene expression in response to various stimuli, such as LPS or Pam2CSK4. Kandasamy et al. (2011) used dermal fibroblasts as a model cell to predict the immune responses of dairy cattle following an intramammary E. coli challenge. In their study, animals classified as a high-responding phenotype experienced more 


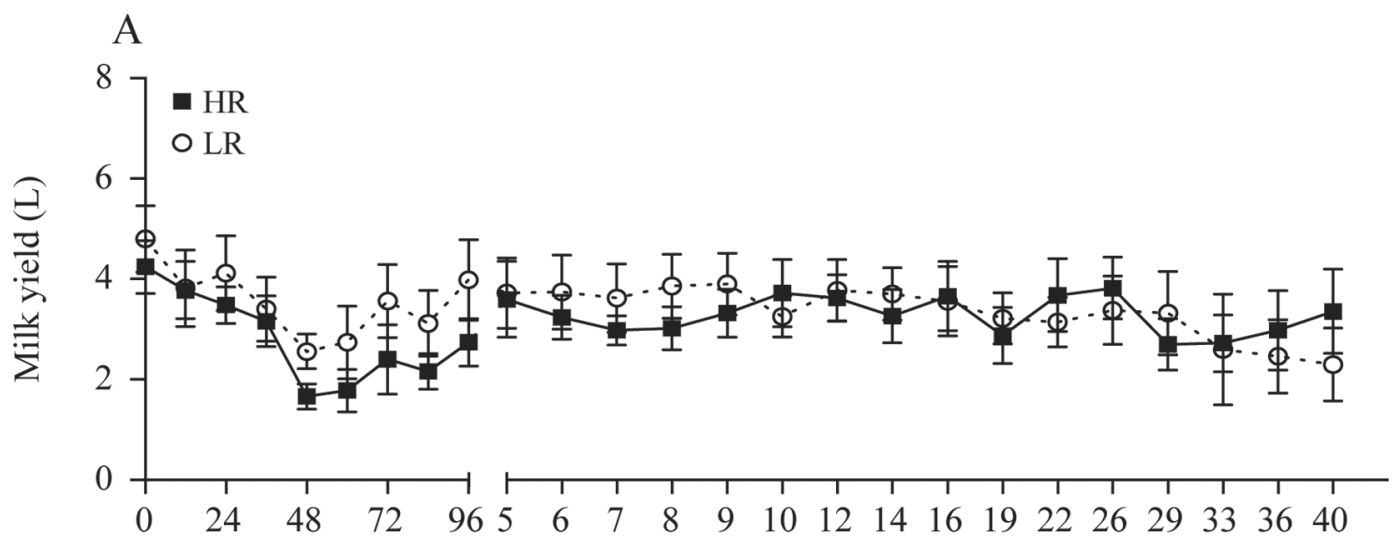

B

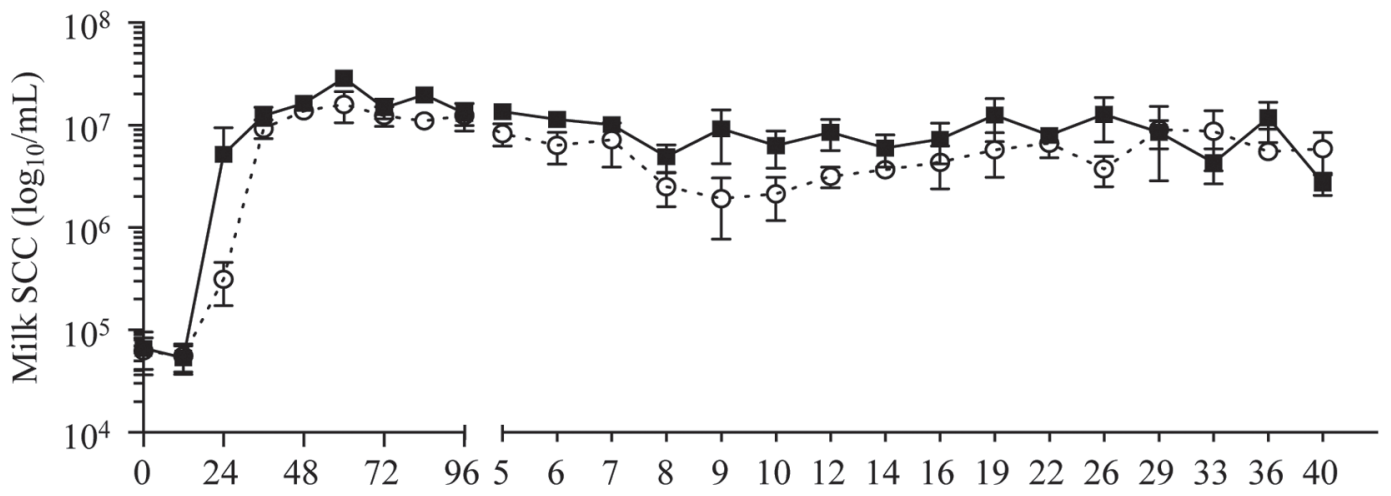

$\mathrm{C}$

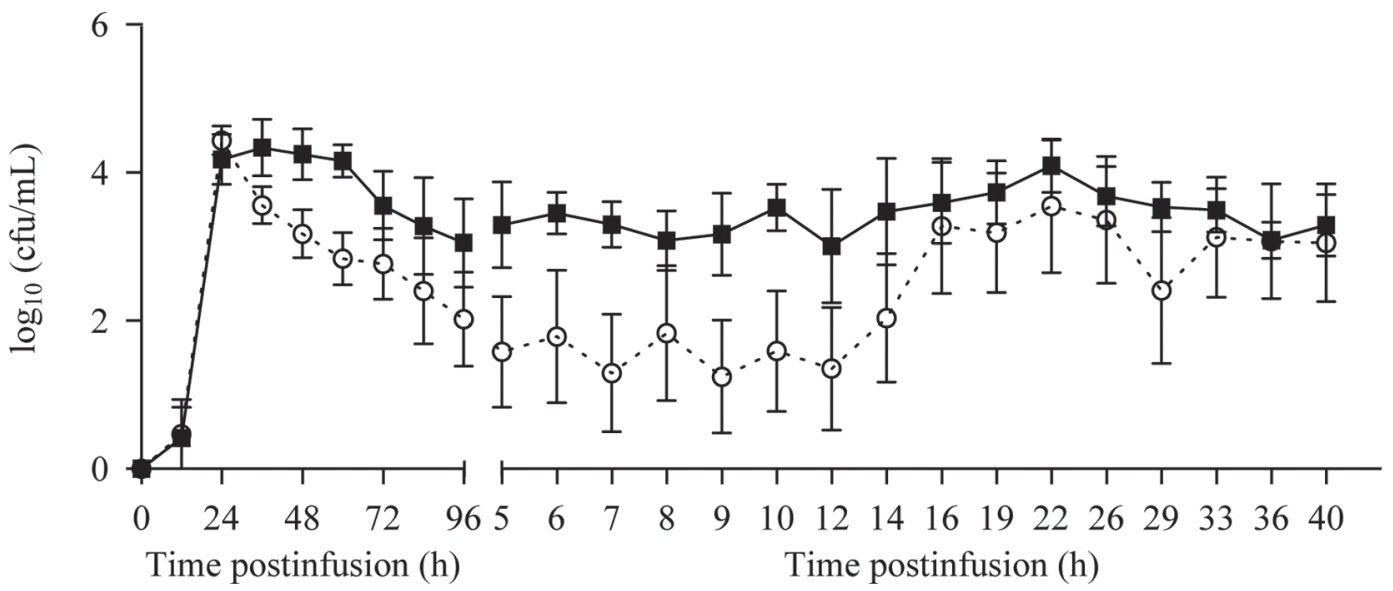

Figure 3. The low-responder ( $\mathrm{LR} ; \mathrm{n}=5)$ and high-responder $(\mathrm{HR})$ animals $(\mathrm{n}=5)$ received an infusion of Staphylococcus aureus in the right hind quarter, after which milk yield from the infected quarter (A), milk SCC (B), and bacteria counts (C) were monitored. Milk SCC and bacteria counts were $\log _{10}$ transformed. Values are expressed as mean \pm SEM. There was no significant difference in milk yield between LR and HR animals during the challenge. Milk SCC was different between the 2 groups throughout the challenge, with the LR animals experiencing reduced $(P<0.05)$ SCC in milk from the right hind quarter when compared with the HR. Staphylococcus aureus was recovered from the right hind quarter of all animals by $24 \mathrm{~h}$ postchallenge. There was no significant difference in average milk bacteria count between the LR and HR animals throughout the trial, although 2 of the LR cleared the infection (d 3 and 4), with 1 of these becoming measurably reinfected by d 14 . The other 3 quarters of each cow served as control quarters and were culture negative throughout the challenge. 
A

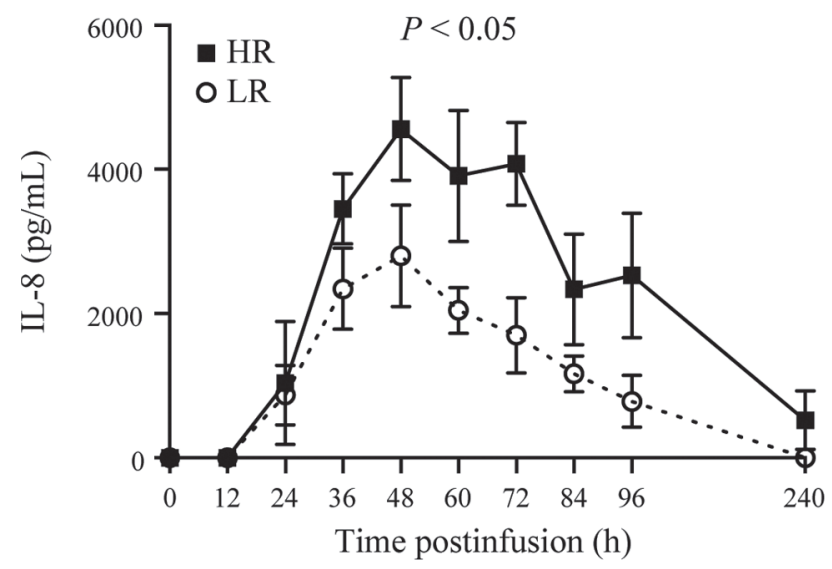

B

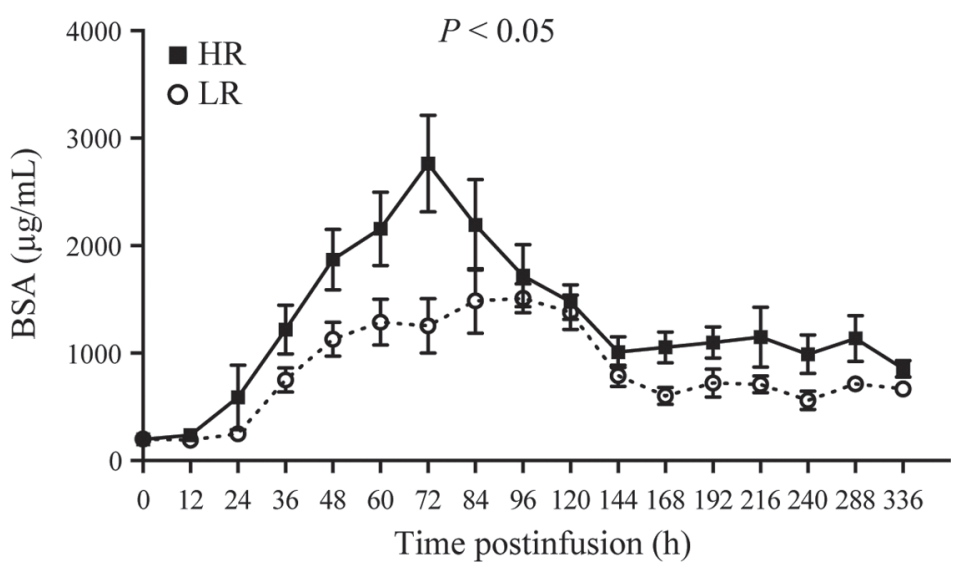

Figure 4. Concentrations of IL-8 (A) and BSA (B) were determined in whey from the right hind quarter of the low-responder $(\mathrm{LR}$; $\mathrm{n}=5$ ) and high-responder $(\mathrm{HR})$ animals $(\mathrm{n}=5)$ following an intramammary infusion of Staphylococcus aureus. Values represent the mean \pm SEM for the 2 groups. The HR had increased $(P<0.05)$ IL-8 and BSA concentrations when compared with the low responders.

mammary tissue damage, and an elevated SCC during the resolution phase of the infection compared with the low-responding animals, yet rates of bacterial clearance were similar between phenotypes. In the current study, we used a similar strategy to examine the relation between fibroblast stimulation with Pam2CSK4 and host immune responses following a $S$. aureus challenge.

Previously, we found inconsistent and generally modest production of IL- 8 by fibroblast cultures when stimulated with live, heat-killed, or UV-killed $S$. aureus (data not presented). Others have also reported limited responses of cultured mammary epithelial cells to heat-inactivated S. aureus (Günther et al., 2011; Fu et al., 2013). As a substitute, we choose to use stimulation with the synthetic ligand, PAM2, which has been shown to activate the TLR2/6 pathway in murine macrophages and B lymphocytes in a similar manner as gram-positive bacteria (Buwitt-Beckmann et al., 2005). Our fibroblasts secreted reproducible and easily detectable levels of IL-8 following PAM2 treatment, with a range in responsiveness among the cultures from the 50 individual cows. Furthermore, we found significant correlations between 2 proinflammatory markers (IL8 and IL-6) that are produced following activation of the TLR2/6 pathway, indicating that the range in IL-8 response phenotype of these animals was not solely due to polymorphisms in the IL- 8 gene. We further went on to demonstrate the stability of the IL- 8 response phenotype over time in cultures established from replicate biopsies obtained before and after the animals were challenged with $S$. aureus, and found that the response phenotype was not altered after the experimental intramammary infection. Finally, the response to PAM2 was mirrored to some extent by the responses to LPS and IL-1 $\beta$. These 2 ligands are recognized via different receptors (TLR 4 and the IL-1 $\beta$ receptor, respectively); however, upon ligand recognition, portions of the intracellular signaling cascades from all 3 ligands converge, leading to common activation of downstream transcription factors such as NF- $\kappa \mathrm{B}$, activator protein 1 (AP1), and interferon regulatory factor 3 (IRF3) (Flannery and Bowie, 2010; Takeuchi and Akira, 2010). This moderate similarity between responses to various ligands suggests that fibroblast response phenotype to PAM2 is not solely due to ligand recognition, but also incorporates signaling pathway differences.

We selected 5 low- and 5 high-ranked animals to determine if their ex vivo phenotype was reflected in their in vivo response to an intramammary challenge with $S$. aureus. The selected challenge strain was originally recovered from the mammary glands of several animals at a Vermont dairy farm that were experiencing chronic, subclinical infections with elevated milk SCC (Barlow et al., 2013). It was determined to be of the sequence type 8 multilocus sequence type that has also been isolated from other naturally infected dairy animals in Turkey (Türkyilmaz et al., 2010), The Netherlands (van den Borne et al., 2010), and Switzerland (Sakwinska et al., 2011).

Whereas milk SCC increased in both the HR and LR groups following the challenge, a more rapid influx of immune cells observed in the HR. Considerable increases of IL-8 in milk from HR following the challenge likely played a role in the greater influx of neutrophils into the infected gland due to its role as a chemoattractant. However, this chemokine is but one representative member of a family of neutrophil chemoattractants, such as chemokine (C-X-C motif) ligand (CXCL)1, 

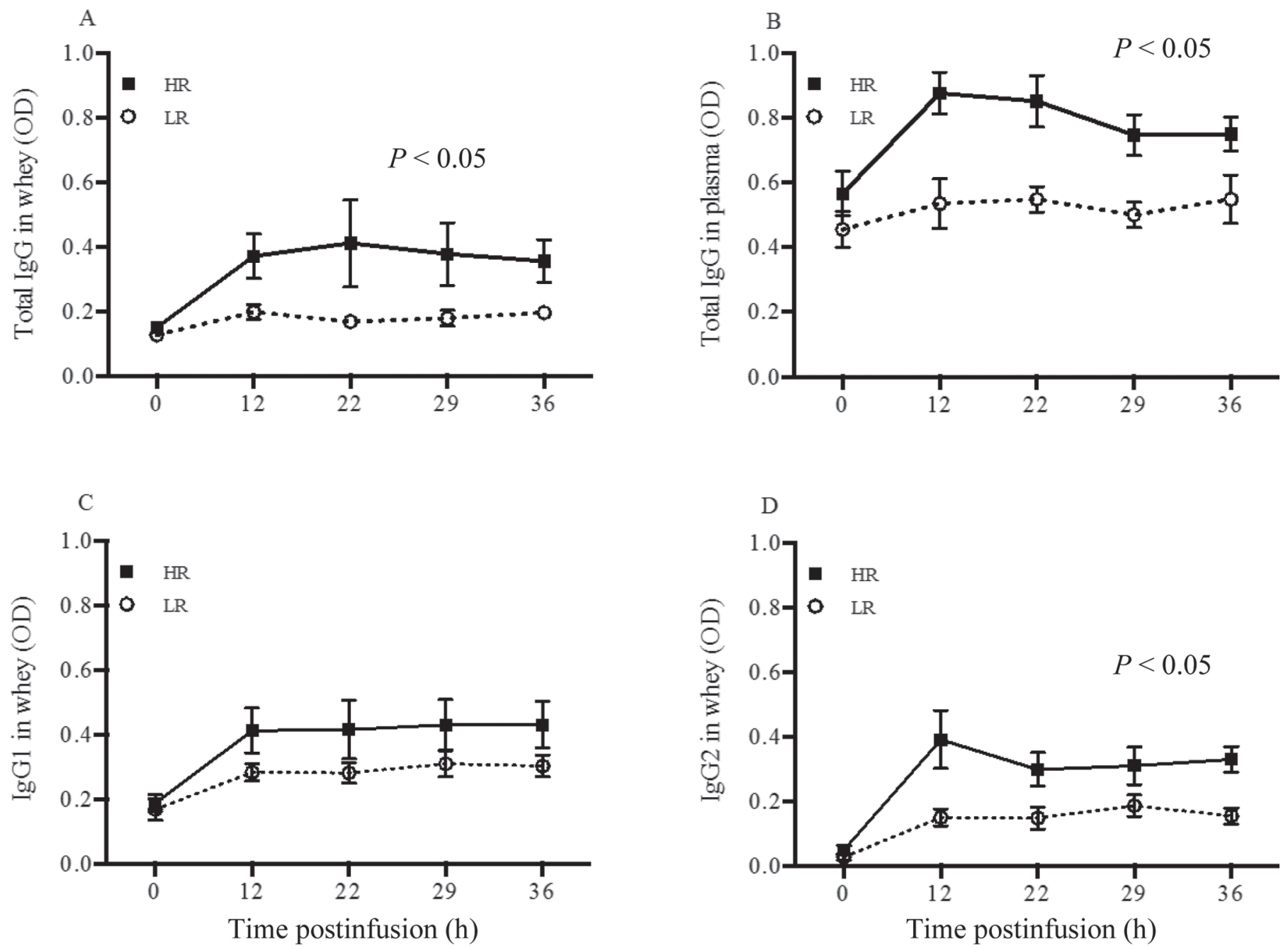

Figure 5. Total levels of anti-Staphylococcus aureus $\operatorname{IgG}$ were determined via an ELISA (represented as optical density values) in whey and plasma of the 5 low-responder (LR) and 5 high-responder (HR) animals following challenge. Infection by $S$. aureus increased levels of total IgG in challenged quarter whey $(\mathrm{A})$ and plasma $(\mathrm{B})$ in both groups, and they were significantly greater $(P<0.05)$ in the HR compared with the LR animals. The levels of $2 \mathrm{IgG}$ isotypes, $\mathrm{IgG}_{1}$ and $\mathrm{IgG}_{2}$, in whey from the challenged quarter were determined and are presented in $(\mathrm{C})$ and (D), respectively. Values represent the mean \pm SEM of the LR and $\mathrm{HR}$ animals. The HR animals had an increase $(P<0.05)$ in total levels of IgG ${ }_{2}$ in whey compared with the LR animals, whereas $\operatorname{IgG}_{1}$ levels were similar between LR and HR animals.

CXCL2, CXCL3, and CXCL6, which are induced in bovine cells following stimulation of the TLR pathway; as such, IL8 may not be the only chemokine contributing to differences in neutrophil influx (Griesbeck-Zilch et al., 2009; Kandasamy and Kerr, 2012). The more rapid and sustained influx of neutrophils in the HR offered little advantage in containing the infection. Rather, 2 of the 5 LR were able to initially clear the infection; although 1 was reinfected $13 \mathrm{~d}$ later or perhaps had not completely cleared the infection. In addition, the LR animals suffered less severe mammary damage when using milk BSA as an indicator of breakdown of the mammary epithelial barrier.

A considerable body of evidence exists suggesting that physiological states such as early lactation result in immunosuppression leading to a reduced functionality of neutrophils entering into the infected gland (Burvenich et al., 2007). It has also been suggested in several review articles that a rapid influx of cells into the gland is a major factor in controlling $E$. coli mastitis (Paape et al., 2002; De Schepper et al., 2008). However, this suggestion is not easily tested. In one study, 19 early lactation cows were classified as being moderate or severe responders based on lower or higher reactive oxygen species-generating capacity of their blood neutrophils. All animals were then challenged with intramammary E. coli and the severe responders had a slightly delayed increase in SCC compared with the moderate responders, as well as an increase in milk colony-forming units (Vandeputte-Van Messom 

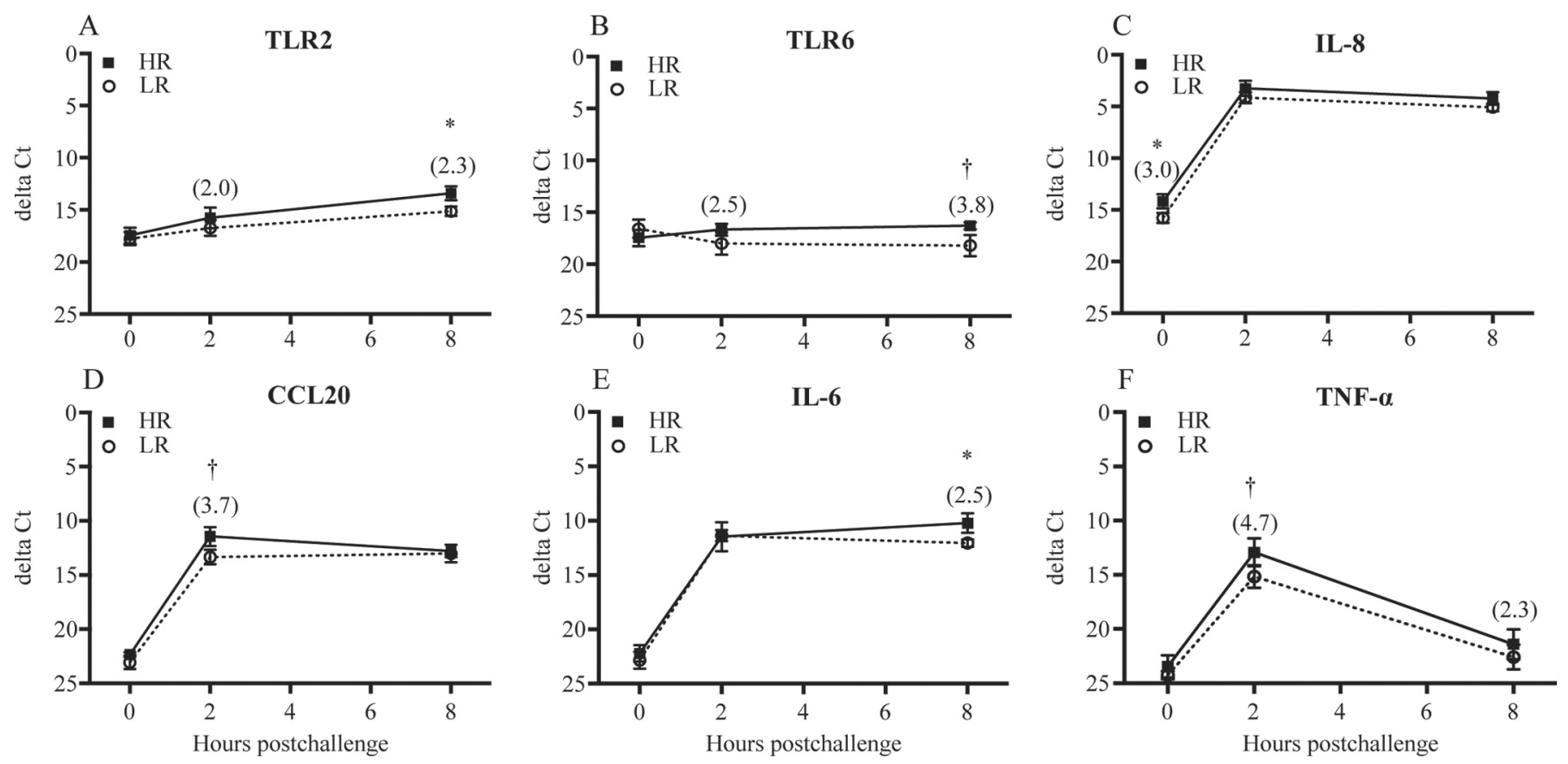

Figure 6. Aliquots of dermal fibroblasts from the 10 challenged animals $[n=5$ and 5 for low responder (LR) and high responder (HR), respectively] were revived, treated with a synthetic toll-like receptor $2 / 6$ agonist (PAM2; $200 \mathrm{ng} / \mathrm{mL}$ ), and total RNA extracted at h 0 (control conditions), 2, and 8 for quantification of gene expression. Results are expressed as delta Ct (cycle threshold) compared with $\beta$-actin. Expression fold differences between LR and HR cultures are indicated by the values in parenthesis above 0,2 , or $8 \mathrm{~h}$ time points, with values indicating the greater expression in HR cultures. $\dagger P<0.1,{ }^{*} P<0.05$. Values are mean \pm SEM. TLR $=$ toll-like receptor; TNF $=$ tumor necrosis factor; CCL20 $=$ chemokine (C-C motif) ligand 20.

et al., 1993). Further studies are needed to evaluate this delayed response hypothesis. Studies with immunosuppressive agents that cause a delay in neutrophil influx could be of use in evaluating the role of moderate changes in the speed of neutrophil influx in containing mastitis pathogens. Interestingly, in cows chronically infected with $S$. aureus, a 3-d treatment with cortisol had little effect on milk SCC or colony-forming units, whereas the more potent dexamethasone had marked effects on reducing milk yield, which were reflected in large increases as opposed to immunosuppressive decreases in both milk SCC and colony-forming units (Burton and Kehrli, 1995).

In contrast to delayed influx, several cytokine-based strategies have been investigated as a means to stimulate additional neutrophil recruitment. These studies have revealed inconsistent effects as mastitis therapeutics (Sordillo et al., 1997). Recently, Kauf et al. (2007) investigated the use of LPS as a possible treatment for $S$. aureus mastitis due to its immunostimulating properties with the hypothesis that a greater inflammatory response can enhance clearance of the bacteria. They infected mammary quarters with $S$. aureus and then $24 \mathrm{~h}$ later LPS or saline control was infused into challenged glands. The LPS treatment rapidly caused large increases in SCC and milk BSA and a moderate reduction in colony-forming units at the peak of the acute response. However, bacteria recovery rates from these quarters were actually higher for the remainder of the induced inflammation period. The results clearly indicated that, at least with an $S$. aureus mastitis, additional recruitment of leukocytes into the gland did not aid in bacterial clearance and may actually be detrimental by causing further damage to the epithelial layer, thus exposing additional sites for bacterial attachment. In our study, the heightened inflammatory response and over production of immune mediators in the HR animals led to higher amounts of collateral damage in the mammary gland, whereas the delayed and reduced influx of neutrophils observed in the LR was associated with a general trend of reduced bacterial burden.

It has been shown that anti-inflammatory treatments administered around the time of an intramammary challenge can reduce the severity of clinical symptoms and promote restoration of prechallenge milk production and quality (Lohuis et al., 1988; Yeiser et al., 2012; Sipka et al., 2013). Similarly, the use of pharmaceutical agents aimed at reducing the magnitude of the immune response has demonstrated positive effects in human health. For instance, the pathologies of several human diseases, including rheumatoid arthritis (McInnes and 
Schett, 2007), psoriasis (Tamilselvi et al., 2013), and type 2 diabetes (Crook, 2004), are due to an excessive immune response with large numbers of infiltrating immune cells and abnormally high production of proinflammatory cytokines, such as IL-1 $\beta$ and tumor necrosis factor- $\alpha$. Many of the treatment options for these diseases focus on reducing or inhibiting immune mediators, such as tumor necrosis factor- $\alpha$ (Armuzzi et al., 2014), the JAK (Janus tyrosine kinase) pathway (Hsu and Armstrong, 2014), and IL-1 $\beta$ (Dinarello, 2011). Use of anti-inflammatories as a treatment option in bovine mastitis requires further investigation to determine what magnitude of immune response is effective for clearing a mammary infection while minimizing the damage to the host, as well as the effect of variable immune responses in the success or failure of mastitis treatments.

The development of a vaccine that generates an effective antibody response against $S$. aureus has been the focus of many studies (Leitner et al., 2003; Lee et al., 2005; Middleton et al., 2006). In each of these studies, the levels of sera antibodies toward $S$. aureus increased following vaccination. To determine the level of protection conferred from the vaccine, experimental intramammary challenges were completed in 2 of these studies. Leitner et al. (2003) administered a vaccine containing $3 S$. aureus strains causing mastitis in dairy cows and then subsequently challenged vaccinated animals with 1 of those strains. Animals receiving the vaccine were protected against an IMI significantly more than controls, with infection rates of 35 and $90 \%$ for vaccinated and control animals, respectively. Clinical symptoms, including SCC, were milder in the vaccinated animals postchallenge as well. In the second study, Middleton et al. (2006) performed an intramammary challenge on 47 animals, 36 of which had been vaccinated against $S$. aureus. Rates of persistent $S$. aureus mammary infections were similar between the vaccinated and control animals and no differences in milk SCC, bacteria counts, or clinical mastitis scores were observed. The conflicting results between vaccine effectiveness could be due to different vaccine formulations between studies, but it also reinforces the fact that variation is present in the immune response between animals, even following vaccination.

Within our challenged animals, activation of the adaptive immune system was confirmed by an increase in total IgG antibody levels to S. aureus from prechallenge levels in both milk and plasma in the HR animals, although the LR animals showed a much smaller increase. To further examine the antibody-mediated response, we chose to focus on the 2 predominant $\operatorname{IgG}$ isotypes of the mammary gland, $\operatorname{IgG}_{1}$ and $\mathrm{IgG}_{2}$, and how their concentrations in the milk would be influ- enced after an experimental mammary infection. The $\mathrm{IgG}_{1}$ isotype is the predominant one found in mammary secretions of both healthy and infected glands, primarily due to its selective transport across the epithelial lining by the IgG Fc receptor (Barrington et al., 1997). Concentrations of $\operatorname{IgG}_{2}$, normally low in healthy milk, will increase quickly after mammary infections due to the antibody binding to the Fc receptor on neutrophils in the blood and being co-recruited to the site of infection (Atalla et al., 2010). In agreement with other experimental challenge models (Bourry and Poutrel, 1996; Tollersrud et al., 2006), there was an increase in anti- $S$. aureus total IgG present in whey and plasma, and both $\operatorname{IgG}_{1}$ and $\operatorname{IgG}_{2}$ observed in the whey from the HR animals. However, elevated concentrations of strain-specific antibodies did not offer an advantage in pathogen clearance for the HR animals. In the current study, basal levels of serum and milk antibodies were similar between the 2 groups. It is unknown if higher levels of preexisting antibodies would have mitigated the propensity for an animal to develop a chronic infection following an experimental challenge.

A panel of genes was selected to further investigate the basis of the low- versus high-response phenotype of the fibroblasts from the 10 challenged animals. Differences in expression levels of receptors and proteins involved in pathogen recognition can affect the propensity for an animal to develop an infection (Fonseca et al., 2011; Kandasamy and Kerr, 2012; Novák, 2014). Enhanced pathogen detection, due to genetic or epigenetic differences between animals, could be a major factor differentiating the high versus low phenotype observed in our fibroblasts. Koets et al. (2010) observed an SNP in the extracellular portion of the bovine TLR2 gene that was more prevalent in animals seemingly resistant to Mycobacterium avium paratuberculosis infection. This SNP resulted in greater proinflammatory cytokine production from monocytes as well as enhanced T-cell activation following challenge. The extracellular receptors (TLR2 and TLR6) are thought to play a key role in detection of $S$. aureus (Nakayama et al., 2012) and we observed greater expression of both receptors in high-responding cultures following PAM2 stimulation. This greater expression would correspond to the significantly enhanced transcription of $I L-6$, and clear trend for enhanced transcription of $C C L 20$ and $T N F-\alpha$.

Tumor necrosis factor- $\alpha$ and IL- 6 are considered potent proinflammatory cytokines that can activate lymphocytes and the production of acute phase proteins (Bannerman, 2009). Elevated concentrations of serum IL-6 have been shown to be correlated with disease severity in naturally infected cows (Hagiwara et al., 2001), suggesting that IL-6 can be used as a second marker for a high-responding phenotype. Expression 
levels and protein concentrations of IL-6 were greater in our HR fibroblast cultures, perhaps reflecting the enhanced TLR2 and TLR6 expression in these cells compared with LR cultures. Quite surprisingly, we did not find a significant difference in $I L-8$ gene expression between the groups after stimulation with PAM2. The slight numerical difference in gene expression at 2 and 8 h post-PAM2 as measured by qRT-PCR appears insufficient to cause the nearly 4-fold difference in protein accumulation in media $24 \mathrm{~h}$ post-PAM2. This suggests that determination of actual protein production at $24 \mathrm{~h}$ postchallenge is a more sensitive indicator of the response phenotype. In a similar previous study (Kandasamy and Kerr, 2012) we did find 3-fold higher $I L-8$ gene expression following an 8-h stimulation of selected high- versus low-responding fibroblast cultures with LPS. Ideally, the response phenotype would be best classified using a combination of the production of multiple proteins and the expression of a panel of inflammation associated genes.

In the present study, we presented evidence for the use of dermal fibroblasts as a cell model for a dairy animal's in vivo immune response following an intramammary challenge with $S$. aureus. Animals selected as HR based upon their cellular response mounted a stronger innate immune response demonstrated by higher levels of IL- 8 and SCC present in the milk of the challenged gland compared with LR. Tissue damage to the infected quarter, determined by increased levels of BSA in whey, was more extensive in the HR group as well. High-responding animals also elicited a stronger adaptive immune response, indicated by an increase in anti- $S$. aureus antibodies in whey from the challenge quarter, but no protective advantage was observed for these animals. The LR and HR animals were initially chosen based on extreme differences in the responsiveness of their fibroblasts following challenge with TLR agonists, and these differences were corroborated in the immune responses following an intramammary challenge. Our study indicates that dermal fibroblasts may be useful to explore potential genetic or epigenetic causes for the diversity in immune responses to mastitis causing pathogens between dairy animals.

\section{REFERENCES}

Akira, S., K. Takeda, and T. Kaisho. 2001. Toll-like receptors: Critical proteins linking innate and acquired immunity. Nat. Immunol. 2:675-680.

Armuzzi, A., P. Lionetti, C. Blandizzi, R. Caporali, S. Chimenti, L. Cimino, P. Gionchetti, G. Girolomoni, G. Lapadula, A. Marchesoni, A. Marcellusi, F. S. Mennini, C. Salvarani, and R. Cimaz. 2014. Anti-TNF agents as therapeutic choice in immune-mediated inflammatory diseases: Focus on adalimumab. Int. J. Immunopathol. Pharmacol. 27:11-32.
Atalla, H., C. Gyles, B. Wilkie, K. Leslie, and B. Mallard. 2009. Somatic cell scores and clinical signs following experimental intramammary infection of dairy cows with a Staphylococcus aureus small colony variant ( $S$. aureus SCV) in comparison to other bovine strains. Vet. Microbiol. 137:326-334.

Atalla, H., B. Wilkie, C. Gyles, K. Leslie, L. Mutharia, and B. Mallard. 2010. Antibody and cell-mediated immune responses to Staphylococcus aureus small colony variants and their parental strains associated with bovine mastitis. Dev. Comp. Immunol. 34:1283-1290.

Ballou, M. A. 2012. Growth and development symposium: Inflammation: Role in the etiology and pathophysiology of clinical mastitis in dairy cows. J. Anim. Sci. 90:1466-1478.

Bannerman, D. D. 2009. Pathogen-dependent induction of cytokines and other soluble inflammatory mediators during intramammary infection of dairy cows. J. Anim. Sci. 87:10-25.

Bannerman, D. D., H. R. Springer, M. J. Paape, A. C. W. Kauf, and J. P. Goff. 2008. Evaluation of breed-dependent differences in the innate immune responses of Holstein and Jersey cows to Staphylococcus aureus intramammary infection. J. Dairy Res. 75:291-301.

Barkema, H. W., Y. H. Schukken, and R. N. Zadoks. 2006. Invited review: The role of cow, pathogen, and treatment regimen in the therapeutic success of bovine Staphylococcus aureus mastitis. J. Dairy Sci. 89:1877-1895.

Barlow, J. W., R. N. Zadoks, and Y. H. Schukken. 2013. Effect of lactation therapy on Staphylococcus aureus transmission dynamics in two commercial dairy herds. BMC Vet. Res. 9:28.

Barrington, G. M., T. E. Besser, W. C. Davis, C. C. Gay, J. J. Reeves, and T. B. McFadden. 1997. Expression of immunoglobulin G(1) receptors by bovine mammary epithelial cells and mammary leukocytes. J. Dairy Sci. 80:86-93.

Bougarn, S., P. Cunha, F. B. Gilbert, A. Harmache, G. Foucras, and P. Rainard. 2011. Staphylococcal-associated molecular patterns enhance expression of immune defense genes induced by IL-17 in mammary epithelial cells. Cytokine 56:749-759.

Bourry, A., and B. Poutrel. 1996. Bovine mastitis caused by Listeria monocytogenes: Kinetics of antibody responses in serum and milk after experimental infection. J. Dairy Sci. 79:2189-2195.

Brand, B., A. Hartmann, D. Repsilber, B. Griesbeck-Zilch, O. Wellnitz, C. Kuhn, S. Ponsuksili, H. H. Meyer, and M. Schwerin. 2011. Comparative expression profiling of E. coli and $S$. aureus inoculated primary mammary gland cells sampled from cows with different genetic predispositions for somatic cell score. Genet. Sel. Evol. 43:24.

Burton, J. L., and M. E. Kehrli Jr. 1995. Regulation of neutrophil adhesion molecules and shedding of Staphylococcus aureus in milk of cortisol- and dexamethasone-treated cows. Am. J. Vet. Res. 56:997-1006.

Burvenich, C., D. D. Bannerman, J. D. Lippolis, L. Peelman, B. J. Nonnecke, M. E. Kehrli Jr., and M. J. Paape. 2007. Cumulative physiological events influence the inflammatory response of the bovine udder to Escherichia coli infections during the transition period. J. Dairy Sci. 90(E- Suppl. 1):E39-E54.

Burvenich, C., V. Van Merris, J. Mehrzad, A. Diez-Fraile, and L. Duchateau. 2003. Severity of $E$. coli mastitis is mainly determined by cow factors. Vet. Res. 34:521-564.

Buwitt-Beckmann, U., H. Heine, K. H. Wiesmuller, G. Jung, R. Brock S. Akira, and A. J. Ulmer. 2005. Toll-like receptor 6-independent signaling by diacylated lipopeptides. Eur. J. Immunol. 35:282289.

Crook, M. 2004. Type 2 diabetes mellitus: A disease of the innate immune system? An update. Diabet. Med. 21:203-207.

De Schepper, S., A. De Ketelaere, D. D. Bannerman, M. J. Paape, L. Peelman, and C. Burvenich. 2008. The toll-like receptor-4 (TLR4) pathway and its possible role in the pathogenesis of Escherichia coli mastitis in dairy cattle. Vet. Res. 39:5.

Dinarello, C. A. 2011. Interleukin-1 in the pathogenesis and treatment of inflammatory diseases. Blood 117:3720-3732.

Flannery, S., and A. G. Bowie. 2010. The interleukin-1 receptor-associated kinases: Critical regulators of innate immune signalling. Biochem. Pharmacol. 80:1981-1991. 
Fonseca, I., G. R. Antunes, D. S. Paiva, C. C. Lange, S. E. Guimaraes, and M. F. Martins. 2011. Differential expression of genes during mastitis in Holstein-Zebu crossbreed dairy cows. Genet. Mol. Res. 10:1295-1303.

Fu, Y., E. Zhou, Z. Liu, F. Li, D. Liang, B. Liu, X. Song, F. Zhao, X. Fen, D. Li, Y. Cao, X. Zhang, N. Zhang, and Z. Yang. 2013 Staphylococcus aureus and Escherichia coli elicit different innate immune responses from bovine mammary epithelial cells. Vet. Immunol. Immunopathol. 155:245-252.

Gilbert, F. B., P. Cunha, K. Jensen, E. J. Glass, G. Foucras, C. Robert-Granie, R. Rupp, and P. Rainard. 2013. Differential response of bovine mammary epithelial cells to Staphylococcus aureus or Escherichia coli agonists of the innate immune system. Vet. Res. 44:40.

Green, B. B., S. Kandasamy, T. H. Elsasser, and D. E. Kerr. 2011. The use of dermal fibroblasts as a predictive tool of the toll-like receptor 4 response pathway and its development in Holstein heifers. J. Dairy Sci. 94:5502-5514.

Griesbeck-Zilch, B., M. Osman, C. Kuhn, M. Schwerin, R. H. Bruckmaier, M. W. Pfaffl, A. Hammerle-Fickinger, H. H. Meyer, and O. Wellnitz. 2009. Analysis of key molecules of the innate immune system in mammary epithelial cells isolated from marker-assisted and conventionally selected cattle. J. Dairy Sci. 92:4621-4633.

Günther, J., K. Esch, N. Poschadel, W. Petzl, H. Zerbe, S. Mitterhuemer, H. Blum, and H. M. Seyfert. 2011. Comparative kinetics of Escherichia coli- and Staphylococcus aureus-specific activation of key immune pathways in mammary epithelial cells demonstrates that $S$. aureus elicits a delayed response dominated by interleukin-6 (IL-6) but not by IL-1A or tumor necrosis factor alpha. Infect. Immun. 79:695-707.

Hagiwara, K., H. Yamanaka, K. Hisaeda, S. Taharaguchi, R. Kirisawa, and H. Iwai. 2001. Concentrations of IL-6 in serum and whey from healthy and mastitic cows. Vet. Res. Commun. 25:99-108.

Heinrichs, A. J., C. M. Jones, S. M. Gray, P. A. Heinrichs, S. A. Cornelisse, and R. C. Goodling. 2013. Identifying efficient dairy heifer producers using production costs and data envelopment analysis. J. Dairy Sci. 96:7355-7362.

Hertl, J. A., Y. H. Schukken, F. L. Welcome, L. W. Tauer, and Y. T. Grohn. 2014. Pathogen-specific effects on milk yield in repeated clinical mastitis episodes in Holstein dairy cows. J. Dairy Sci. 97:1465-1480.

Hsu, L., and A. W. Armstrong. 2014. JAK inhibitors: Treatment efficacy and safety profile in patients with psoriasis. J. Immunol. Res. 2014:283617.

Kandasamy, S., B. B. Green, A. L. Benjamin, and D. E. Kerr. 2011. Between-cow variation in dermal fibroblast response to lipopolysaccharide reflected in resolution of inflammation during Escherichia coli mastitis. J. Dairy Sci. 94:5963-5975.

Kandasamy, S., and D. E. Kerr. 2012. Genomic analysis of betweencow variation in dermal fibroblast response to lipopolysaccharide. J. Dairy Sci. 95:3852-3864.

Kauf, A. C., B. T. Vinyard, and D. D. Bannerman. 2007. Effect of intramammary infusion of bacterial lipopolysaccharide on experimentally induced Staphylococcus aureus intramammary infection. Res. Vet. Sci. 82:39-46.

Kawai, T., and S. Akira. 2007. Signaling to NF-kappaB by Toll-like receptors. Trends Mol. Med. 13:460-469.

Koets, A., W. Santema, H. Mertens, D. Oostenrijk, M. Keestra, M. Overdijk, R. Labouriau, P. Franken, A. Frijters, M. Nielen, and V. Rutten. 2010. Susceptibility to paratuberculosis infection in cattle is associated with single nucleotide polymorphisms in Toll-like receptor 2 which modulate immune responses against Mycobacterium avium subspecies paratuberculosis. Prev. Vet. Med. 93:305-315.

Kornalijnslijper, J. E., A. J. Daemen, T. van Werven, T. A. Niewold, V. P. Rutten, and E. N. Noordhuizen-Stassen. 2004. Bacterial growth during the early phase of infection determines the severity of experimental Escherichia coli mastitis in dairy cows. Vet. Microbiol. 101:177-186.

Lahouassa, H., E. Moussay, P. Rainard, and C. Riollet. 2007. Differential cytokine and chemokine responses of bovine mammary epithelial cells to Staphylococcus aureus and Escherichia coli. Cytokine $38: 12-21$.

Lee, J. W., C. N. O'Brien, A. J. Guidry, M. J. Paape, K. A. ShaferWeaver, and X. Zhao. 2005. Effect of a trivalent vaccine against Staphylococcus aureus mastitis lymphocyte subpopulations, antibody production, and neutrophil phagocytosis. Can. J. Vet. Res. 69:11-18

Leitner, G., E. Lubashevsky, A. Glickman, M. Winkler, A. Saran, and Z. Trainin. 2003. Development of a Staphylococcus aureus vaccine against mastitis in dairy cows. I. Challenge trials. Vet. Immunol. Immunopathol. 93:31-38.

Leitner, G., B. Yadlin, A. Glickman, M. Chaffer, and A. Saran. 2000. Systemic and local immune response of cows to intramammary infection with Staphylococcus aureus. Res. Vet. Sci. 69:181-184.

Lohuis, J. A., W. Van Leeuwen, J. H. Verheijden, A. S. Van Miert, and A. Brand. 1988. Effect of dexamethasone on experimental Escherichia coli mastitis in the cow. J. Dairy Sci. 71:2782-2789.

McInnes, I. B., and G. Schett. 2007. Cytokines in the pathogenesis of rheumatoid arthritis. Nat. Rev. Immunol. 7:429-442.

Middleton, J. R., J. Ma, C. L. Rinehart, V. N. Taylor, C. D. Luby, and B. J. Steevens. 2006. Efficacy of different Lysigin formulations in the prevention of Staphylococcus aureus intramammary infection in dairy heifers. J. Dairy Res. 73:10-19.

Nakayama, H., K. Kurokawa, and B. L. Lee. 2012. Lipoproteins in bacteria: Structures and biosynthetic pathways. FEBS J. 279:42474268.

NMC. 2011. Recommended mastitis control program. Accessed Aug. 1, 2014. http://www.nmconline.org/docs/NMCchecklistInt.pdf.

Novák, K. 2014. Functional polymorphisms in Toll-like receptor genes for innate immunity in farm animals. Vet. Immunol. Immunopathol. 157:1-11.

Olde Riekerink, R. G., H. W. Barkema, D. F. Kelton, and D. T. Scholl. 2008. Incidence rate of clinical mastitis on Canadian dairy farms. J. Dairy Sci. 91:1366-1377.

Paape, M., J. Mehrzad, X. Zhao, J. Detilleux, and C. Burvenich. 2002. Defense of the bovine mammary gland by polymorphonuclear neutrophil leukocytes. J. Mammary Gland Biol. Neoplasia 7:109-121.

Pareek, R., O. Wellnitz, R. Van Dorp, J. Burton, and D. Kerr. 2005. Immunorelevant gene expression in LPS-challenged bovine mammary epithelial cells. J. Appl. Genet. 46:171-177.

Park, B. S., D. H. Song, H. M. Kim, B. S. Choi, H. Lee, and J. O. Lee. 2009. The structural basis of lipopolysaccharide recognition by the TLR4-MD-2 complex. Nature 458:1191-1195.

Revelo, X. S., and M. R. Waldron. 2012. In vitro effects of Escherichia coli lipopolysaccharide on the function and gene expression of neutrophils isolated from the blood of dairy cows. J. Dairy Sci. 95:2422-2441.

Rogers, K. M., D. H. Black, and R. Eberle. 2007. Primary mouse dermal fibroblast cell cultures as an in vitro model system for the differential pathogenicity of cross-species herpesvirus papio 2 infections. Arch. Virol. 152:543-552.

Sakwinska, O., M. Giddey, M. Moreillon, D. Morisset, A. Waldvogel, and P. Moreillon. 2011. Staphylococcus aureus host range and human-bovine host shift. Appl. Environ. Microbiol. 77:5908-5915.

Schramm, F., A. Kern, C. Barthel, S. Nadaud, N. Meyer, B. Jaulhac, and N. Boulanger. 2012. Microarray analyses of inflammation response of human dermal fibroblasts to different strains of Borrelia burgdorferi sensu stricto. PLoS ONE 7:e40046.

Schukken, Y. H., J. Gunther, J. Fitzpatrick, M. C. Fontaine, L. Goetze, O. Holst, J. Leigh, W. Petzl, H. J. Schuberth, A. Sipka, D. G. Smith, R. Quesnell, J. Watts, R. Yancey, H. Zerbe, A. Gurjar, R. N. Zadoks, and H. M. Seyfert. 2011. Host-response patterns of intramammary infections in dairy cows. Vet. Immunol. Immunopathol. 144:270-289

Schukken, Y. H., K. E. Leslie, D. A. Barnum, B. A. Mallard, J. H. Lumsden, P. C. Dick, G. H. Vessie, and M. E. Kehrli. 1999. Experimental Staphylococcus aureus intramammary challenge in late lactation dairy cows: Quarter and cow effects determining the probability of infection. J. Dairy Sci. 82:2393-2401.

Sipka, A., A. Gurjar, S. Klaessig, G. E. Duhamel, A. Skidmore, J. Swinkels, P. Cox, and Y. Schukken. 2013. Prednisolone and cefa- 
pirin act synergistically in resolving experimental Escherichia coli mastitis. J. Dairy Sci. 96:4406-4418.

Sohn, E. J., M. J. Paape, E. E. Connor, D. D. Bannerman, R. H. Fetterer, and R. R. Peters. 2007. Bacterial lipopolysaccharide stimulates bovine neutrophil production of TNF-alpha, IL-1beta, IL-12 and IFN-gamma. Vet. Res. 38:809-818.

Sol, J., O. C. Sampimon, H. W. Barkema, and Y. H. Schukken. 2000. Factors associated with cure after therapy of clinical mastitis caused by Staphylococcus aureus. J. Dairy Sci. 83:278-284.

Sordillo, L. M., K. Shafer-Weaver, and D. DeRosa. 1997. Immunobiology of the mammary gland. J. Dairy Sci. 80:1851-1865.

Sordillo, L. M., and K. L. Streicher. 2002. Mammary gland immunity and mastitis susceptibility. J. Mammary Gland Biol. Neoplasia $7: 135-146$

Takeuchi, O., and S. Akira. 2010. Pattern recognition receptors and inflammation. Cell 140:805-820.

Tamilselvi, E., D. Haripriya, M. Hemamalini, G. Pushpa, and S. Swapna. 2013. Association of disease severity with IL-1 levels in methotrexate-treated psoriasis patients. Scand. J. Immunol. $78: 545-553$.

Taraktsoglou, M., U. Szalabska, D. A. Magee, J. A. Browne, T. Sweeney, E. Gormley, and D. E. MacHugh. 2011. Transcriptional profiling of immune genes in bovine monocyte-derived macrophages exposed to bacterial antigens. Vet. Immunol. Immunopathol. 140:130-139.

Tollersrud, T., A. H. Kampen, and K. Kenny. 2006. Staphylococcus aureus enterotoxin $\mathrm{D}$ is secreted in milk and stimulates specific antibody responses in cows in the course of experimental intramammary infection. Infect. Immun. 74:3507-3512.

Türkyilmaz, S., S. Tekbiyik, E. Oryasin, and B. Bozdogan. 2010. Molecular epidemiology and antimicrobial resistance mechanisms of methicillin-resistant Staphylococcus aureus isolated from bovine milk. Zoonoses Public Health 57:197-203. van den Borne, B. H., M. Nielen, G. van Schaik, M. B. Melchior, T. J. Lam, and R. N. Zadoks. 2010. Host adaptation of bovine Staphylococcus aureus seems associated with bacteriological cure after lactational antimicrobial treatment. J. Dairy Sci. 93:2550-2558.

Vandeputte-Van Messom, G., C. Burvenich, E. Roets, A. M. MassartLeen, R. Heyneman, W. D. Kremer, and A. Brand. 1993. Classification of newly calved cows into moderate and severe responders to experimentally induced Escherichia coli mastitis. J. Dairy Res. 60:19-29.

Wang, J., K. Hori, J. Ding, Y. Huang, P. Kwan, A. Ladak, and E. E. Tredget. 2011. Toll-like receptors expressed by dermal fibroblasts contribute to hypertrophic scarring. J. Cell. Physiol. 226:12651273.

Wellnitz, O., and D. E. Kerr. 2004. Cryopreserved bovine mammary cells to model epithelial response to infection. Vet. Immunol. Immunopathol. 101:191-202.

Wenz, J. R., L. K. Fox, F. J. Muller, M. Rinaldi, R. Zeng, and D. D. Bannerman. 2010. Factors associated with concentrations of select cytokine and acute phase proteins in dairy cows with naturally occurring clinical mastitis. J. Dairy Sci. 93:2458-2470.

Wenz, J. R., F. B. Garry, and G. M. Barrington. 2006. Comparison of disease severity scoring systems for dairy cattle with acute coliform mastitis. J. Am. Vet. Med. Assoc. 229:259-262.

Yeiser, E. E., K. E. Leslie, M. L. McGilliard, and C. S. Petersson-Wolfe. 2012. The effects of experimentally induced Escherichia coli mastitis and flunixin meglumine administration on activity measures, feed intake, and milk parameters. J. Dairy Sci. 95:4939-4949.

Zähringer, U., B. Lindner, S. Inamura, H. Heine, and C. Alexander. 2008. TLR2 - Promiscuous or specific? A critical re-evaluation of a receptor expressing apparent broad specificity. Immunobiology 213:205-224. 